\title{
Aspekty etyczno-prawne legalizacji marihuany i innych narkotyków miękkich
}

\author{
Andrzej Kobyliński \\ Wydział Filozofii Chrześcijańskiej \\ Uniwersytet Kardynała Stefana Wyszyńskiego \\ ul. Wóycickiego 1/3, 01-938 Warszawa, a.kobylinski@uksw.edu.pl
}

\begin{abstract}
Streszczenie
Głównym celem artykułu jest prezentacja najważniejszych aspektów etycznych i prawnych legalizacji marihuany i innych narkotyków miękkich. Spór o legalizację dostępu do narkotyków jest przejawem rewolucji moralnej, która dokonuje się obecnie w wymiarze globalnym. W ostatnim dziesięcioleciu nastąpiło w wielu krajach silne przesunięcie nastrojów opinii publicznej na korzyść reformy polityki narkotykowej. Argumenty związane z zakazem dostępu do narkotyków i reformą polityki narkotykowej są obecnie przedmiotem poważnych kontrowersji. Problem prawnego dostępu do narkotyków stanowi bardzo złożoną kwestię interdyscyplinarną, która wymaga rzetelnej diagnozy z pogranicza etyki, medycyny, filozofii prawa, socjologii i filozofii politycznej. Etyczna ocena stosowania narkotyków i ich dystrybucji powinna zawsze poprzedzać przyjęcie określonych rozwiązań o charakterze prawnym.
\end{abstract}

\section{Stowa kluczowe}

narkotyki, marihuana, liście konopi, legalizacja narkotyków, godność człowieka, narkomania, narkotyki miękkie

\section{Wprowadzenie}

Problem legalnego dostępu do narkotyków jest bardzo złożonym zagadnieniem interdyscyplinarnym, które wymaga rzetelnej interpretacji na pograniczu etyki, medycyny, filozofii prawa, socjologii czy filozofii polityki. Najczęściej dzieli się narkotyki na miękkie (marihuana, haszysz, grzyby psylocybinowe itp.) oraz twarde (kokaina, heroina, opium itp.). Za narkotyki miękkie uznaje się zazwyczaj te preparaty psychoaktywne, które są „bardziej bezpieczne” i uzależniają człowieka w mniejszym stopniu niż ich wersja twarda. Narkotyki twarde uzależniają bardzo szybko, mają też poważne następstwa zdrowotne. Natomiast narkotyki miękkie potrzebują więcej czasu, aby uzależnić człowieka, nie mają zbyt wielu następstw fizycznych, powodują głównie problemy psychiczne, emocjonalne i osobowościowe.

Kryteria takiego podziału są wątpliwe, nieostre i kwestionowane przez wielu naukowców. Jeśli nawet rozróżnienie narkotyków na miękkie i twarde budzi wiele zastrzeżeń metodologicznych, medycznych czy etycznych, to ma ono duże znaczenie praktyczne w wymiarze przyjmowanych rozwiązań prawnych. W tych państwach, w których dochodzi do liberalizacji przepisów regulujących dostęp 
do narkotyków, wprowadza się legalizację ich wersji miękkiej, utrzymując w mocy zakazy dotyczące posiadania, wytwarzania czy handlu narkotykami twardymi.

W 2011 r. Organizacja Narodów Zjednoczonych opublikowała dokument pt. "Globalna Komisja ds. Polityki Narkotykowej” (Global Commission on Drug Policy), w którym stwierdzono, że walka z narkotykami na poziomie międzynarodowym została przegrana, prowadząc do katastrofalnych skutków w wielu krajach świata. W konsekwencji nową formą rozwiązania tego problemu powinna być liberalizacja przepisów dotyczących kontroli wytwarzania, posiadania i konsumpcji narkotyków - szczególnie $\mathrm{w}$ formie miękkiej.

Dokument ONZ, postulujący legalizację niektórych rodzajów narkotyków, został podpisany przez byłych prezydentów wielu krajów, byłych szefów licznych organizacji międzynarodowych, wielu znanych przedstawicieli kultury, bankowości i życia gospodarczego. Wśród najważniejszych sygnatariuszy można wskazać m.in. Kofiego Annana - byłego sekretarza generalnego ONZ, Javiera Solanę - byłego sekretarza generalnego Rady Unii Europejskiej, dwóch byłych prezydentów USA - Jimmy'ego Cartera i Billa Clintona (por. Web-o1).

W jaki sposób władze państwowe powinny rozwiązywać problem dostępu do narkotyków? Jakie argumenty są formułowane w debacie publicznej przez zwolenników i przeciwników legalizacji marihuany i innych środków odurzających? Co sądzą na temat liberalizacji prawa antynarkotykowego przedstawiciele różnych nurtów współczesnej etyki? Jakie rozwiązania prawne proponują obecnie zwolennicy legalnego dostępu do narkotyków miękkich we Włoszech?

Głównym celem rozważań podjętych w tym artykule jest prezentacja najważniejszych aspektów etycznych i prawnych kwestii dostępu do narkotyków oraz analiza sporu światopoglądowego i politycznego, jaki toczy się obecnie w tej sprawie w kraju nad Tybrem oraz w wielu innych państwach na świecie.

\section{Problem szkodliwości narkotyków miękkich}

Do podziału na narkotyki miękkie i twarde używa się wielu różnych kryteriów. Zwolennicy takiego rozróżnienia twierdzą przede wszystkim, że narkotyki miękkie nie uzależniają fizycznie. Takie przekonanie trudno uzasadnić naukowo, ponieważ oprócz uzależnienia fizycznego, które powoduje różne objawy ze strony organizmu człowieka, istnieje jeszcze uzależnienie psychiczne - dużo groźniejsze i trudniejsze do wyleczenia. Nie ulega wątpliwości, że narkotyki miękkie uzależniają w sensie psychicznym.

Stopień uzależnienia psychicznego i fizycznego zależy tak naprawdę od specyfiki konkretnego organizmu. Nikt nie jest w stanie przewidzieć, ile razy można zażyć substancję potencjalnie uzależniającą, aby było to bezpieczne dla zdrowia i nie powodowało uzależnienia. Rozwój nałogu ma związek nie tyle z brakiem silnej woli, ile $\mathrm{z}$ uwarunkowaniami genetycznymi konkretnej osoby. Nie ma de facto narkotyków, które nie uzależniają. Jedna substancja psychoaktywna uzależnia szybciej, inna wolniej (por. Pach 2009; Piotrowski 2008; Szukalski 2005).

W 2014 r. na łamach międzynarodowego czasopisma naukowego „Forensic Science International" ukazał się ważny artykuł badaczy z Niemiec, którzy poddali wnikliwej analizie medycznej ciała dwóch młodych i zdrowych mężczyzn, zmarłych nagle z powodu zażycia pochodnych konopi (por. Hartung, Kauferstein 2014). Zwłoki poddano m.in. badaniom genetycznym, toksykologicznym i histopatologicznym, które doprowadziły do wykluczenia długiej listy ewentualnej przyczyny śmierci. W ten sposób badacze doszli do wniosku, że bezpośrednią przyczyną tych dwóch zgonów były powikłania sercowo-naczyniowe spowodowane paleniem marihuany, tzn. suszonych i czasem sfermentowanych kwiatostanów żeńskich roślin konopi, zawierających substancje psychoaktywne.

Autorzy artykuły zakwestionowali w ten sposób szeroko rozpowszechnioną tezę 
o niskiej toksyczności kannabinoidów. Czym są te preparaty? Kannabinoidy to nazwa każdej substancji chemicznej, bez względu na swoje pochodzenie lub strukturę, która łączy receptory kannabinoidowe ciała i mózgu, posiadające podobne skutki do tych produkowanych przez konopie (por. Firenzuoli, Epifani 2015; Cinquini 2016). Kannabinoidy stanowią dużą grupę preparatów, w której najczęściej wyróżnia się trzy rodzaje: fitokannabinoidy, endokannabinoidy i kannabinoidy syntetyczne.

Badania przeprowadzone przez naukowców niemieckich wykazały wiele niebezpieczeństw o charakterze sercowo -naczyniowym u osób biorących narkotyki miękkie - narażonych w ten sposób na negatywne skutki toksyczności kannabinoidów. Zażywanie pochodnych konopi prowadzi m.in. do wzrostu szybkości bicia serca i ciśnienia krwi w organizmie. Autorzy artykułu podnieśli także problem stosowania marihuany w celach terapeutycznych jako środka przeciwbólowego. Ich zdaniem, potrzeba ciągle wielu nowych pogłębionych badań naukowych, aby wykluczyć podawanie pacjentom tych środków przeciwbólowych na bazie konopi, które mogą być szkodliwe dla zdrowia i życia.

Wyniki badań zaprezentowane przez naukowców z Niemiec potwierdzają wiele ustaleń amerykańskiego Narodowego Instytutu Narkomanii (National Institute on Drug Abuse - NIDA), który od wielu lat zajmuje się analizą przyczyn i skutków używania narkotyków oraz wykorzystaniem współczesnej wiedzy naukowej do podwyższenia poziomu jakości zdrowia ludzi w wymiarze jednostkowym i społecznym. NIDA koncentruje swoje badania na konsekwencjach związanych z konsumpcją narkotyków oraz na mechanizmach neurobiologicznych, behawioralnych i społecznych, które towarzyszą używaniu tego rodzaju preparatów. Misją Narodowego Instytutu Narkomanii jest także upowszechnianie wyników badań naukowych w celu poprawy profilaktyki i leczenia zaburzeń spowodowanych narkomanią, a także zwiększenie świadomości społecznej na temat uzależnienia od narkotyków jako choroby mózgu (por. Web-o2).

W wielu opracowaniach przygotowanych przez NIDA stwierdza się, że używanie przez dłuższy czas marihuany może prowadzić do zmniejszenia ilorazu inteligencji oraz osłabienia zdolności zapamiętywania i koncentracji. Jednym z negatywnych skutków konsumpcji narkotyków są także problemy z koordynacją psychomotoryczną oraz różnego rodzaju zaburzenia w sferze neuropoznawczej. Marihuana oraz inne narkotyki oddziałują bezpośrednio na korę przedczołową, ograniczając zdolności decyzyjne jednostki - nawet w odniesieniu do samego zażywania narkotyków. Zdaniem Nory Volkow, dyrektorki tej ważnej instytucji federalnej w USA, konsumpcja marihuany jest niezwykle szkodliwa przede wszystkim dla nastolatków, ponieważ wyrządza im poważną szkodę w procesie kształtowania dojrzałości umysłowej.

\section{Depersonalizacja bytu ludzkiego}

W 2015 r. Massimo Introvigne, Alfredo Mantovano i Giovanni Serpelloni opublikowali we Włoszech ciekawą książkę pt. Wolność od narkotyków (por. Introvigne, Mantovano 2015). Autorzy tego opracowania poddali analizie socjologicznej, prawnej i moralnej problem dostępu do narkotyków i konsekwencji ich używania. Ich zdaniem, można mówić o czterech stereotypach, które funkcjonują obecnie w domenie publicznej, gdy chodzi o konsumpcję substancji psychoaktywnych.

Po pierwsze, istnieje fałszywe przekonanie, że są narkotyki „złe” i „dobre”, szkodliwe dla zdrowia i pozwalające spędzić miło wieczór, prowadzące do uzależnienia i ułatwiające nawiązanie relacji z innymi ludźmi. To rozróżnienie jest czysto arbitralne i nie ma żadnych racjonalnych podstaw. Coraz więcej, wiele badań naukowych prowadzonych $\mathrm{w}$ różnych krajach potwierdza szkody organiczne i psychiczne, spowodowane zażywaniem także narkotyków miękkich.

Po drugie, w wielu debatach na temat dostępu do narkotyków twierdzi się, że każdy 
człowiek sam odpowiada za własne zdrowie i w konsekwencji może czynić to, co chce, a władze państwowe nie powinny w tym przeszkadzać w żaden sposób, respektując wolność i autonomię swoich obywateli. Argumentacja tego rodzaju nie może być jednak stosowana bez jakichkolwiek ograniczeń. Owszem, ważne są kategorie wolności i autonomii jednostki, ale istnieje także interes społeczny i zasada solidarności - dlatego wolność i autonomia obywateli podlegają różnym ograniczeniem, np. z powodu przepisów ruchu drogowego, które nakładają m.in. obowiązek stosowania kasków przez motocyklistów.

Po trzecie, w domenie publicznej funkcjonuje stereotyp, że także alkohol i tytoń szkodzą zdrowiu tak samo jak narkotyki, a nikt nie dąży do ograniczenia dostępności tych produktów na rynku. Niektórzy formułują zarzut, że nie wolno zakazywać dostępu do narkotyków miękkich, zezwalając na sprzedaż wyrobów alkoholowych. Argument jest słaby, ponieważ alkohol spożywany w odpowiedniej formie i ilości nie szkodzi zdrowiu. Dopiero nadużywanie alkoholu wiąże się $\mathrm{z}$ negatywnymi konsekwencjami dla zdrowia fizycznego i psychicznego. Przy zwykłym spożyciu alkoholu nie występują ostre epizody psychotyczne o charakterze przejściowym, które są typowym skutkiem zażywania narkotyków. Podobne głębokie różnice dotyczą narkotyków i tytoniu.

Po czwarte, istnieje fałszywe przekonanie, że legalizacja narkotyków wpływa na osłabienie organizacji kryminalnych, które zajmują się dystrybucją tego rodzaju substancji na czarnym rynku. W krajach, w których zalegalizowano narkotyki miękkie i wprowadzono monopol państwa na handel tego rodzaju środkami odurzającymi, nie odnotowano osłabienia organizacji przestępczych zajmujących się rynkiem narkotykowym. Badania przeprowadzone w USA pokazują, że legalizacja marihuany dla celów terapeutycznych lub rekreacyjnych zwiększa przede wszystkim średnie spożycie tej substancji na statystycznego mieszkańca. Legalizacja nie dotyczy osób nieletnich, które stanowią bardzo liczną grupę konsumentów i dalej korzystają z czarnego rynku. Legalizacja nie likwiduje podziemia narkotykowego, ale ogranicza jego wielkość do osób nieletnich oraz do mniej zamożnych klientów dorosłych, którzy preferują tańszy towar, dostępny na czarnym rynku, zamiast droższych substancji, sprzedawanych na rynku oficjalnym zgodnie z obowiązującym prawem (por. Web-o7).

W sporze dotyczącym dostępu do narkotyków i konsekwencji ich używania niezwykle ważną rolę odgrywają argumenty o charakterze etycznym (por. Risé 2007; White 2012; Murray, Gaylin 2011). Autorzy akcentujący szkodliwość stosowania narkotyków zwracają szczególnie uwagę na depersonalizację bytu ludzkiego i degradację naszej wolności. Niestety, bardzo często narkotyki niszczą naszą godność i czynią z ludzi niewolników. „Godność człowieka - wystarczy przeczytać sobie niezapomniane strony Sokratesa, Arystotelesa, Pascala, Kanta oraz wielu innych wielkich i wybitnych myślicieli - polega także na cudownej zdolności myślenia i działania w sposób wolny, podczas gdy narkotyki mogą prowadzić do zaburzenia postrzegania rzeczywistości" (Ludovici 2016). Używając narkotyków, abdykujemy w pewnym stopniu z naszej przyrodzonej godności, ponieważ dobrowolnie zgadzamy się na utratę świadomości częściowo lub całkowicie - w konsekwencji nie zachowujemy się jako podmioty moralne wolne i racjonalne.

Gdy chodzi o ocenę etyczną, czyny i zachowania narkomanów kwalifikują się jako niemoralne, ponieważ godzą w godność osoby ludzkiej, w porządek moralny i społeczny. „Człowiek powołany jest do realizowania dobra, szczęścia, do rozwoju osobowego, do rozwoju i współtworzenia wartości etycznych, transcendentalnych dobra, prawdy, piękna, do miłości bliźniego i miłości Stwórcy. Narkotyki prowadzą do zaburzeń poznawczych, motywacyjnych, godzą w dobro osoby ludzkiej i realizowanie wartości wyższych" (Cekiera 2005: 314-315).

Z punktu widzenia etycznego, zasadnicze znaczenie ma nie tyle rodzaj stosowanych 
preparatów czy też sposób ich oddziaływania na organizm człowieka, ile raczej cel ich stosowania: medyczny lub pozamedyczny. Tadeusz Ślipko odróżnia „akty odurzenia (narkotycznego) terapeutycznego" i "akty odurzenia (narkotycznego) euforycznego". Jego zdaniem, działania narkotyzujące, których celem medycznym jest osiągnięcie własnego uspokojenia wewnętrznego lub uśmierzenie bólu, nie wykazują wewnętrznego zła moralnego. Natomiast działania narkotyczne ukierunkowane na euforyczne zakłócenie funkcjonowania świadomości moralnej należy uznać za akt wewnętrznie zły i poważne naruszenie porządku moralnego. Szczytową formą euforycznych działań narkotycznych jest uzależnienie od narkotyków, traktowane jako jednostka chorobowa.

Ślipko twierdzi, że „narkomanię - obok wewnętrznego zła tkwiącego w jej wstępnych, jeszcze dobrowolnych aktach charakteryzują także poważne zmiany osobowościowe. Do najważniejszych zalicza się osłabienie woli, dezintegracja duchowego życia jednostki, inklinacje do aktów niezgodnych z prawem czy moralnością (np. samobójstwo). Pociąga to za sobą cały szereg ujemnych reperkusji szerzącej się narkomanii w życiu społecznym, przede wszystkim niebezpieczne procesy degeneracji młodego pokolenia. Narkomania - obiektywnie rzecz biorąc - jest więc ciężkim złem moralnym" (Ślipko 2005: 146).

\section{Rozwiązania prawne obowiązujące we Włoszech}

Gwałtowny rozwój używania narkotyków rozpoczął się w świecie zachodnim na fali rewolucji obyczajowej 1968 r. Ówczesny projekt nowej moralności, wyzwolenia społecznego oraz liberalnego porządku prawnego otworzył drogę do rozwoju narkomanii jako wielkiej plagi społecznej. W ostatnich latach kwestia liberalizacji przepisów dotyczących marihuany i innych narkotyków miękkich stała się w niektórych krajach przedmiotem wielkich debat społecznych. Jednym z takich państw są Stany Zjednoczone, gdzie toczy się obecnie ostra dyskusja światopoglądowa dotycząca tego problemu. Z badań socjologicznych wynika, że marihuany używa regularnie kilkanaście milionów Amerykanów. $\mathrm{Z}$ jednej strony, według przepisów federalnych, marihuana jest wciąż w USA narkotykiem, z drugiej - poszczególne stany tworzą własne prawo legalizujące dostęp do tego rodzaju środków odurzających.

W 1996 r. Kalifornia zdecydowała się jako pierwsza na legalizację marihuany dla celów medycznych. Obecnie już w połowie stanów pacjenci mogą kupować marihuanę na receptę jako środek przeciwbólowy. W 2012 r. Waszyngton i Kolorado stały się dwoma pierwszymi stanami legalizującymi pochodną konopi dla celów rekreacyjnych. W 2014 r. podobne rozwiązania prawne wprowadzono w stanach Kolorado, Oregon i Alaska. Na 8 listopada 2016 r., w dniu ogólnonarodowych wyborów prezydenckich, w sprawie legalizacji marihuany zostały zaplanowane referenda stanowe w Kalifornii, Nevadzie, Maine i Arizonie.

W Europie bardzo ciekawy spór etyczny i prawny na temat legalizacji narkotyków miękkich toczy się obecnie we Włoszech. W kraju nad Tybrem zażywanie narkotyków stanowi poważny problem społeczny. Różne formy narkotyków są zażywane przez cztery miliony mieszkańców Włoch, natomiast populacja narkomanów potrzebujących leczenia sięga 430.ooo. Mieszkańcy tego kraju kupują każdego roku narkotyki, których wartość wycenia się na 12 miliardów euro.

We Włoszech, podobnie jak w innych krajach zachodnich, rozwój narkomanii sięga swymi korzeniami rewolucji obyczajowej 1968 r. Dopiero w 1990 r. zostało przyjęte prawo ograniczające dostęp do narkotyków. Ustawa nr 162, nazywana potocznie ustawą Vassalli - Russo Jervolino, od nazwisk dwóch ministrów odpowiedzialnych za przygotowanie tego dokumentu, zaostrzyła przepisy wcześniej obowiązujące, które okazały się zbyt liberalne i ułatwiły w kraju nad Tybrem rozwój narkomanii. Ustawa Vassalli - Russo Jervolino z 1990 r. wprowadziła jasno określone sankcje administracyjne 
i karne, gdy chodzi o wytwarzanie narkotyków, ich posiadanie, handel i konsumpcję. Zmiana prawa przyczyniła się bardzo szybko do ograniczenia zgonów z powodu przedawkowania narkotyków, zwiększenia ilości narkotyków rekwirowanych przez władze państwowe oraz wzrostu liczby osób uzależnionych, które poddały się odpowiedniemu leczeniu.

Niestety, zwolennicy wolnego dostępu do narkotyków - szczególnie Partia Radykalna (Partito Radicale) - doprowadzili w 1993 r. do przeprowadzenia w sprawie legalizacji narkotyków ogólnonarodowego referendum, które uchyliło prawie w całości ustawę z 1990 r. W konsekwencji referendum Włochy powróciły do liberalnego porządku prawnego w kwestii narkotyków z lat 70. i 8o. XX wieku. Referendum przywróciło całkowitą niekaralność używania narkotyków oraz prawną możliwość posiadania nawet poważnej ilości tego rodzaju substancji psychoaktywnych, o ile nie wiązało się to ze sprzedażą, ale np. z konsumpcją grupową (Web-04).

Kolejna zmiana prawa w kraju nad Tybrem nastąpiła na początku 2006 r., gdy została uchwalona ustawa nr 49, nazywana potocznie ustawą Fini - Giovanardi, od nazwisk dwóch ministrów odpowiedzialnych za przygotowanie tego dokumentu. Nowe prawo z 2006 r. zaostrzyło politykę państwa włoskiego wobec narkotyków. Został zlikwidowany wcześniejszy podział na narkotyki miękkie i twarde. W oparciu o badania naukowe, wykazujące szkodliwość takich narkotyków miękkich jak haszysz czy marihuana, potraktowano wszystkie rodzaje narkotyków jako formę środków odurzających i określono precyzyjnie różne sankcje karne i administracyjne w zależności od ilości posiadanego lub sprzedawanego preparatu (por. Web-03).

12 grudnia 2014 r. Trybunał Konstytucyjny Republiki Włoskiej stwierdził niezgodność z włoską konstytucją, z przyczyn formalnych, ustawy Fini - Giovanardi z 2006 r., która regulowała ważny problem etyczno -prawny dostępności i handlu narkotyków w kraju nad Tybrem. Jakie przyczyny formalne stały się podstawą decyzji Trybunału Konstytucyjnego? Ustawa Fini - Giovanardi była de facto konwersją dekretu z mocą ustawy z 30 grudnia 2005 r., który dotyczył organizacji, finansowania i bezpieczeństwa Zimowych Igrzysk Olimpijskich w Turynie w 2006 r. Trybunał Konstytucyjny zakwestionował sposób przekształcenia dekretu $\mathrm{z}$ mocą ustawy w ustawę i w konsekwencji ogłosił wyrok dotyczący niekonstytucyjności ustawy Fini - Giovanardi (por. Web-o4).

W konsekwencji tego wyroku nowy rząd Mattea Renziego, funkcjonujący od $22 \mathrm{lu}$ tego 2014 r., został zmuszony do uchwalenia nowego dekretu z mocą ustawy, który zastąpił prawo wcześniej obowiązujące. Dekret wydany 20 marca 2014 r. i zaaprobowany dwa miesiące później przez Izbę Deputowanych i Senat, wprowadził jednak dość istotną zmianę w porównaniu z ustawą Fini - Giovanardi: zostało przyjęte rozróżnienie na narkotyki lekkie (droghe leggere), nazywane w Polsce narkotykami miękkimi, oraz narkotyki ciężkie (droghe pesanti), będące odpowiednikiem w języku polskim narkotyków twardych. To rozróżnienie otworzyło drogę dla wielu środowisk politycznych i społecznych, aby podjąć odpowiednie działania prowadzące do legalizacji narkotyków miękkich.

Dekret z mocą ustawy z 2014 r. przywrócił także możliwość posiadania narkotyków bez ograniczeń ilościowych dla celów osobistych. W ten sposób de facto uniemożliwiono organom ścigania zatrzymywanie dilerów narkotykowych, którzy zawsze mogą się bronić w ten sposób, że posiadane przez nich narkotyki służą do prywatnej konsumpcji a nie do handlu. Liberalizacja prawa antynarkotykowego doprowadziła w ostatnim czasie do obniżenia dolnej granicy wieku osób biorących substancje psychoaktywne oraz do wzrostu ich spożycia wśród ludzi młodych (por. Web-09).

25 lipca 2016 r. została oficjalnie przedstawiona w Izbie Deputowanych (Camera dei Deputati) inicjatywa ustawodawcza nr 3235, której celem jest zmiana w kraju nad Tybrem prawa regulującego posiadanie oraz 
uprawę konopi i ich pochodnych, czyli tzw. narkotyków miękkich. Warto w tym miejscu dodać, że Izba Deputowanych stanowi we Włoszech odpowiednik naszego Sejmu. System parlamentarny Republiki Włoskiej ma charakter dwuizbowy: Camera dei Deputati oraz Senato. Obydwie izby pełnią w równym stopniu te same funkcje, choć oddzielnie. Projekt ustawy legalizującej narkotyki miękkie został podpisany przez 221 parlamentarzystów z 630 członków Izby Deputowanych. Byli to w większości przedstawiciele partii centrolewicowych i populistycznych, ale także niewielka grupa polityków z partii centroprawicowych.

Jakie rozwiązania zawiera nowa inicjatywa ustawodawcza? Projekt ustawy składa się z dziesięciu paragrafów. Propozycja nowych rozwiązań przewiduje legalizację uprawy maksymalnie 5 sadzonek konopi w celach „rekreacyjnych” (ricreativi) dla osób indywidualnych, tylko pełnoletnich, oraz uprawę maksymalnie 50 sadzonek dla podmiotów non-profit, należących do mieszkańców Włoch, którzy nie mają wyroków skazujących z powodu działalności mafijnej lub handlu narkotykami.

Projekt ustawy przewiduje, że każda osoba może posiadać przy sobie dla własnych celów niewielką ilość narkotyków miękkich (do 5 gramów), natomiast w miejscu zamieszkania do 15 gramów. Ograniczenia stają się bardziej liberalne, jeśli chodzi o cele terapeutyczne - w tym przypadku nie ma ograniczeń ilościowych, konieczne jest jedynie posiadanie odpowiedniej recepty lekarskiej. Projekt wprowadza niekaralność darmowego transferu marihuany w określonych granicach dla celów prywatnych. Dokument depenalizuje darmowe przekazywanie narkotyków miękkich osobom pełnoletnim oraz darmową wymianę między osobami nieletnimi w celach niekomercyjnych. Projekt wprowadza monopol państwa na uprawę, produkcję i sprzedaż konopi. W niektórych warunkach określonych przez prawo władze państwowe mogą udzielić takiej zgody także podmiotom prywatnym. Projekt ustawy reguluje także kwestie fiskalne i handlowe dotyczące m.in. zakaz importu i eksportu konopi oraz wyznaczenia określonych miejsc dystrybucji narkotyków miękkich (por. Web-o8).

Po pierwszym czytaniu projektu i sześciu godzinach debaty parlamentarnej, projekt ustawy został skierowany do Komisji Sprawiedliwości i Spraw Społecznych Izby Deputowanych. Przedstawiciele różnych klubów zgłosili ok. 2.0oo zmian do projektu ustawy. W przypadku tego projektu zastosowano szczególną formę procedowania, która przewiduje pierwsze czytanie bez uwzględnienia uwag i propozycji zmian formułowanych na etapie prac w odpowiednich komisjach parlamentarnych. Autorzy projektu ustawy chcieli w ten sposób dotrzeć do opinii publicznej z oryginalną formą swojego dokumentu. Wszystko wskazuje na to, że w obecnej kadencji parlamentu Republiki Włoskiej (2013-2018) nie ma większych szans na przyjęcie ustawy liberalizującej dostęp do narkotyków miękkich. Podobne stanowisko wyraża także większość opinii publicznej we Włoszech.

\section{Cele terapeutyczne i rekreacyjne narkotyków}

Latem 2016 r. bardzo jasne stanowisko w sprawie projektu legalizacji narkotyków zajęła włoska minister zdrowia Beatrice Lorenzin, która należy do Obozu Ludowego (Area Popolare). Jaką orientację światopoglądową ma to ugrupowanie? Stanowi ono nową formację polityczną, która powstała w 2015 r. jako stowarzyszenie kilku małych organizacji, odwołujących się do wartości chadeckich dawnej włoskiej partii Chrześcijańska Demokracja (Democrazia Cristiana). Obecnie centroprawicowy Obóz Ludowy tworzy koalicję wspierającą rząd Mattea Renziego, zdominowany przez polityków centrolewicowych z Partii Demokratycznej (Partito Democratico). Dwa pozostałe ministerstwa, za które obecnie odpowiada Obóz Ludowy, na podstawie umowy koalicyjnej, to Ministerstwo Spraw Wewnętrznych z ministrem Angelino Alfano oraz Ministerstwo Spraw Regionalnych i Regionów Autonomicznych, którym kieruje Enrico Costa. 
Stanowisko Ministerstwa Zdrowia w sprawie legalizacji narkotyków, wsparte wypowiedziami dwóch pozostałych centroprawicowych ministrów z Obozu Ludowego, jest częścią niezwykle trudnego kompromisu politycznego i moralnego, zawartego między różnymi frakcjami światopoglądowymi koalicji rządzącej w trudnych kwestiach etycznych i bioetycznych (macierzyństwo zastępcze, legalizacja tzw. związków nieformalnych, status związków homoseksualnych, adopcja dzieci przez pary homoseksualne itp.). W ramach tego kompromisu wprowadzono we Włoszech wiosną 2016 r. legalizację małżeństw homoseksualnych. Dwa pierwsze związki jednopłciowe, zgodnie z obowiązującym prawem, zostały oficjalnie zawarte w Mediolanie 5 sierpnia 2016 r., a ceremonii przewodniczył burmistrz tego miasta Beppe Sala.

Gdy chodzi o stanowisko rządu włoskiego w sprawie narkotyków, warto zauważyć, że w 2014 r. minister Beatrice Lorenzin wyraziła zgodę na uprawę konopi i wykorzystanie marihuany w celach terapeutycznych, w warunkach ściśle określonych przez władze państwowe. Lorenzin twierdzi, że jeśli marihuana, morfina czy pochodne opium mogą być przydatne w medycynie, to nie powinno być żadnych przeszkód ze strony władz państwowych, gdy chodzi o wytwarzanie i dystrybucję takich preparatów. W konsekwencji decyzji podjętych przez rząd, w 2015 r. Region Toskanii, jeden z najbardziej liberalnych światopoglądowo regionów Republiki Włoskiej, rozpoczął w ośrodku chemiczno-wojskowym we Florencji realizację programu pilotażowego, którego celem jest produkcja leków na bazie konopi.

W wielu wypowiedziach na temat dostępu do narkotyków Beatrice Lorenzin zwróciła szczególną uwagę na konieczność odróżnienia celów terapeutycznych od celów rekreacyjnych. Stanowisko przyjęte w tej sprawie przez obecny rząd we Włoszech mówi „tak” dla wykorzystania narkotyków w celach medycznych oraz „nie” dla stosowania tych preparatów w celach związanych z szeroko rozumianą rozrywką czy życiem towarzyskim. Stosowanie preparatów medycznych na bazie konopi pozostawia wciąż wiele wątpliwości związanych z negatywnymi skutkami dla zdrowia pacjentów (por. Web-05; Ciabattoni 2004). Niektórzy naukowcy zwracają uwagę na to, że ciągle wiemy bardzo niewiele na temat długoterminowych skutków stosowania kanabiloidów w celach terapeutycznych. W niektórych krajach część opinii publicznej twierdzi, że produkcja leków na bazie konopi może otworzyć furtkę do legalizacji marihuany w celach rekreacyjnych.

Zdaniem szefowej włoskiego Ministerstwa Zdrowia, w walce z plagą narkomanii potrzeba przede wszystkim prewencji, uwrażliwienia społeczeństwa, działalności edukacyjnej, adekwatnych programów wychowawczych. „Młodym, dorosłym, ale także politykom - twierdzi Beatrice Lorenzin - trzeba dać jasny przekaz. Musimy powiedzieć: «Narkotyki szkodzą», ponieważ tak właśnie jest. Cała reszta argumentów tworzy jedynie zamieszanie. Narkotyki niszczą nasze wnętrze, czynią z nas ofiary fałszywych emocji, przyzwyczajają nas do świata nierzeczywistego, w którym wszystko kręci się wokół tego, aby być «poza», w stanie odurzenia" (Picariello 2016).

Beatrice Lorenzin przywołuje w swoim sprzeciwie wobec liberalizacji prawa antynarkotykowego argumenty o charakterze medycznym. Podkreśla, że jej konstytucyjnym obowiązkiem jako ministra jest ochrona zdrowia mieszkańców Republiki Włoskiej. Powołuje się ona w swoich wypowiedziach na badania wielu naukowców, którzy wykazują szkodliwość przyjmowania narkotyków, szczególnie przez osoby w młodym wieku.

Najbardziej wiarygodne badania - zauważa Beatrice Lorenzin - potwierdzają, że narkotyki prowadzą do zaburzenia nastroju, tachykardii, bezsenności, paranoicznych kryzysów lękowych, zachowań psychotycznych, syndromu amotywacyjnego, na dodatek konopie moga prowadzić do uzależnienia kompleksowego, oddziałując na system mózgowy człowieka dotyczący mechanizmu gratyfikacja-nagroda. Dla dzieci poniżej 15 roku życia ryzyko uzależnienia jest bardzo duże, według wiarygodnych 
badań nawet dwa razy większe niż w przypadku osób dorosłych. Palenie tych substancji może być dla dzieci i młodzieży bardzo niebezpieczne, może zaburzyć ich emocjonalność i całe ich życie - już na etapie bardzo delikatnym, jakim jest pokwitanie i dojrzewanie. Gdy jest się młodym, mózg nie jest jeszcze całkowicie ukształtowany, przede wszystkim w przestrzeni, która wytwarza uczucia. Dlatego stosowanie substancji psychotropowych może wpłynąć bardzo poważnie na rozwój życia emocjonalnego. Syndrom motywacyjny może prowadzić do apatii a nawet do narodzin depresji lub syndromów maniakalnych (Picariello 2016).

Z niezwykle ostrą krytyką poglądów Beatrice Lorenzin na temat stosunku władzy państwowej do narkotyków miękkich oraz oceny moralnej stosowania tych preparatów wystąpił m.in. Roberto Saviano - włoski pisarz i dziennikarz, znany także w naszym kraju, zajmujący się w swoich utworach przede wszystkim organizacjami przestępczymi (por. Saviano 2008). W swoim manifeście, skierowanym do opinii publicznej i dotyczącym liberalizacji przepisów prawa regulujących dostęp do środków odurzających, Saviano powtórzył de facto wszystkie stereotypy, jakie od laty są przytaczane jako argumenty na rzecz legalizacji narkotyków miękkich (por. Web-10).

Włoski pisarz i dziennikarz oskarżył przeciwników legalizacji konopi i ich pochodnych oraz innych środków odurzających o brak wiedzy w tej sprawie. Jego zdaniem, prawny zakaz uprawy konopi i posiadania narkotyków jest przyczyną powstania ogromnego mafijnego rynku narkotykowego, którego obroty sięgają każdego roku miliardów euro. Savino twierdzi, że z pieniędzy pochodzących z handlu narkotykami jest finansowana duża część działalności terrorystycznej w Europie i na świecie. Narkotyki miękkie są towarem wymiennym między organizacjami terrorystycznymi i organizacjami mafijnymi. Terroryści sprzedają narkotyki mafii, otrzymując w zamian pieniądze lub broń. Niestety, handel bronią nie tylko w państwach rządzonych przez dyktatorów, ale także w krajach demokratycznych został opanowany przez organizacje przestępcze (por. Web-o6). Savino używa bardzo mocnego wyrażenia, gdy sądzi, że legalizacja konopi i ich pochodnych we Włoszech byłaby „aktem miłości wobec kraju” (un atto d'amore per il paese).

Beatrice Lorenzin stanowczo odrzuciła stanowisko prezentowane przez Savino i wielu innych autorów. Jej zdaniem, tego rodzaju argumentacji nie potwierdza chociażby legalizacja narkotyków miękkich w Holandii. Okazuje się, że koszty medyczne wynikające z leczenia osób stosujących narkotyki są o wiele większe niż korzyści skarbu państwa związane z przejęciem kontroli handlu narkotykami. Co więcej, w kraju tulipanów nie zniknął czarny rynek. Lorenzin stwierdziła, że każdy, kto był w Amsterdamie, wie o tym, że przed wieloma miejscami legalnej sprzedaży narkotyków stoją dilerzy, którzy sprzedają „towar” za połowę ceny. Okazuje się, że zawsze rodzi się legalny rynek lepszej jakości, który nie wyklucza funkcjonowania czarnego rynku gorszej jakości.

Zdecydowanym zwolennikiem depenalizacji posiadania, wytwarzania i używania narkotyków jest we Włoszech m.in. prof. Umberto Veronesi - znany na świecie włoski lekarz onkolog, polityk, dyrektor naukowy Europejskiego Instytutu Onkologicznego (Istituto Europeo di Oncologia) w Mediolanie. Veronesi bierze aktywny udział w debacie publicznej i opowiada się za bardzo liberalnymi rozwiązaniami, gdy chodzi o macierzyństwo zastępcze, małżeństwa homoseksualne czy eutanazję. Fundacja Umberta Veronesiego wydaje własne pismo „The Future of Science and Ethics”, w którym są poddawane analizie interdyscyplinarnej współczesne wyzwania bioetyczne i biotechnologiczne. W styczniu 2016 r. Komitet Etyczny Fundacji Umberta Veronesiego wyraził swoją pozytywną opinię na temat macierzyństwa zastępczego dla par homoseksualnych.

W połowie sierpnia $2016 \mathrm{r}$. temat legalizacji narkotyków miękkich - pomimo wakacji parlamentarnych - pojawił się ponownie we 
włoskiej debacie publicznej. Ożywioną dyskusję wywołała wypowiedź prezesa Narodowego Urzędu Antykorupcyjnego (Autorità nazionale anticorruzione - Anac). Rafaele Cantone stwierdził, że umożliwienie przez władze państwowe dostępu obywatelom do narkotyków miękkich to forma inteligentnej legalizacji (por. Liverani 2016). Prezes Anac był wcześniej zdecydowanym przeciwnikiem legalizacji narkotyków miękkich, jednak ostatnio zmienił radykalnie zdanie. Obecnie uważa, że inteligentna legalizacja chroni ludzi młodych przed jeszcze większym złem, jakim jest bezpośredni kontakt ze światem przestępczym - w niektórych przypadkach „zdobywanie” narkotyków na czarnym rynku sprawia, że młodzi ludzi wchodzą na drogę różnych form przestępczości.

Wśród głosów przeciwników legalizacji narkotyków miękkich szczególnie mocno wybrzmiały opinie narkomanów przebywających w różnego rodzaju wspólnotach terapeutycznych, które we Włoszech są prowadzone przez kościoły, fundacje, stowarzyszenia itp. (por. Ciociola 2016). W kraju nad Tybrem funkcjonują obecnie dziesiątki tego rodzaju wspólnot, w których leczą się tysiące narkomanów. Wspólnoty zaczęły się rozwijać bardzo szybko po przyjęciu odpowiedniej ustawy 13 maja 1978 r. Latem 2016 r. zdecydowanie przeciw legalizacji narkotyków wystąpiły także osoby pracujące na co dzień z narkomanami. W niezwykle wiarygodnych świadectwach lekarze i terapeuci zwrócili uwagę, że najczęściej uzależnienie od narkotyków rozpoczyna się od beztroskiego palenia skrętów i zażywania różnych form narkotyków miękkich czy innych rodzajów środków odurzających.

Jednoznacznie negatywną opinię na temat obecnego projektu ustawy liberalizującej dostęp do narkotyków miękkich wyrazili przedstawiciele Federacji Wspólnot Terapeutycznych (Federazione delle comunità terapeutiche). W swoich wypowiedziach zauważyli, że wprowadzenie monopolu państwa na handel narkotykami może przynieść dodatkowe wpływy finansowe do budżetu, ale jednocześnie zwiększy plagę narkomanii w kraju nad Tybrem. W tym kontekście został podany przykład legalizacji hazardu $\mathrm{z}$ jednej strony, można mówić we Włoszech o większych dochodach z tego tytułu dla skarbu państwa, z drugiej - nastąpił wzrost liczby uzależnień od hazardu i powstały tzw. nowe koszty społeczne.

\section{Podsumowanie}

Problem legalnego dostępu do narkotyków jest bardzo złożonym zagadnieniem interdyscyplinarnym, które wymaga rzetelnej diagnozy na pograniczu etyki, medycyny, filozofii prawa, socjologii czy filozofii polityki. W publikacjach poświęconych tej problematyce oraz w debacie publicznej używa się różnego rodzaju argumentów o charakterze filozoficznym, medycznym, prawnym itp. W tle dyskusji prawnej i politycznej pojawia się pytanie stricte moralne: czy używanie narkotyków oraz różne formy ich wytwarzania i dystrybucji są moralnie dozwolone czy też nie? Należy stwierdzić, że ocena etyczna używania narkotyków i ich dystrybucji powinna poprzedzać przyjęcie konkretnych rozwiązań o charakterze prawnym (por. Ludovici 2016).

Czasami spory światopoglądowe na temat legalnego dostępu do narkotyków przekształcają się w ostre i emocjonalne spory polityczne. W ramach takiej właśnie debaty, jaka toczyła się w kraju nad Tybrem latem 2016 r., stawiano często pytanie, czy włoscy politycy powinni zajmować się liśćmi konopi, gdy terroryści z Państwa Islamskiego atakują Europę (por. Spagnolo 2016).

Spór o legalizację narkotyków miękkich we Włoszech pokazuje bardzo wyraźnie, jak niezwykle trudno osiągnąć dzisiaj stabilny kompromis polityczny w sprawach moralnych i światopoglądowych. Działacze postchadeckiego Obozu Ludowego, którzy są przeciwnikami liberalizacji prawa antynarkotykowego, przekonują, że obecny rząd Mattea Renziego nie jest rządem politycznym, tzn. nie został powołany przez obóz polityczny, który wygrał wybory parlamentarne w lutym 2013 r., ale jest rządem rekonstrukcji, wspieranym także przez część sił 
centroprawicowych, które określają siebie jako „odpowiedzialną centroprawicę” (centrodestra responsabile). W konsekwencji Obóz Ludowy - dla realizacji konkretnych celów, także o charakterze moralnym i światopoglądowym - tworzy koalicję rządową z lewicową Partią Demokratyczną, pozostając jednocześnie w ostrym sporze politycznym z tym ugrupowaniem na poziomie działalności samorządowej. W ramach przyjętego kompromisu politycznego w obecnej koalicji rządzącej, w 2016 r. wprowadzono we Włoszech małżeństwa homoseksualne, nie udzielając jednocześnie poparcia rządowego projektowi ustawy legalizującej dostęp do narkotyków miękkich.

Przeciwnicy liberalizacji przepisów regulujących dostęp do narkotyków zwracają uwagę na konieczność poszanowania godności człowieka, która jest naruszana w przypadku używania narkotyków odbierających część niezwykle ważnego elementu naszego człowieczeństwa, jakim jest świadomość. Liczne badania naukowe pokazują szkodliwość narkotyków miękkich nie tylko w odniesieniu do ciała człowieka, ale także do naszej psychiki. Legalizując marihuanę i inne narkotyki lekkie państwo pozwala na to, że niektórzy obywatele mogą dopuszczać się czynów niemoralnych i kryminalnych, np. kierowcy pod wpływem narkotyków moga powodować wypadki drogowe.

Ważny argumentem przeciw legalizacji narkotyków miękkich jest także mechanizm równi pochyłej - legalny dostęp do tej grupy środków odurzających otwiera puszkę Pandory, tzn. sprawia, że wchodzi się na drogę, która prędzej czy później doprowadzi do legalizacji sprzedaży innych rodzajów narkotyków i de facto zwiększy spożycie substancji psychoaktywnych. Bardzo często marihuana i inne formy narkotyków miękkich są etapem poprzedzającym używanie kokainy, haszyszu czy innych form narkotyków twardych.

Zwolennicy zmiany przepisów antynarkotykowych twierdzą, że legalizacja nie oznacza liberalizacji (por. Guerrieri 2016). Zwracają oni uwagę na to, że przyjęcie odpowiednich rozwiązań prawnych - a więc kontrola uprawy, wytwarzania i dystrybucji narkotyków przez władze państwowe obniża rzekomo poziom konsumpcji tych substancji, ponieważ odbiera im charakter „owocu zakazanego”. Niestety, najczęściej legalizacja narkotyków prowadzi do wzrostu ich spożycia, ponieważ to, co jest legalne, jest coraz częściej postrzegane jako moralnie dozwolone.

W debacie publicznej pojawia się także opinia, że jeśli ktoś dąży do zakazu narkotyków, powinien także zakazać dostępu do alkoholu i innych używek. Jest to argument zdecydowanie nietrafiony. Rozsądne korzystanie $\mathrm{z}$ alkoholu przez osoby dorosłe nie szkodzi zdrowiu i nie prowadzi do przestępstw, natomiast czymś radykalnie odmiennym jest używanie narkotyków, których konsumpcja nawet w niewielkich dawkach może prowadzić do uzależnienia, uszczerbku na zdrowiu i różnego rodzaju zachowań niebezpiecznych.

Spór o legalizację dostępu do narkotyków stanowi ważny element rewolucji moralnej, jaka dokonuje się obecnie w wymiarze globalnym. Nowością ostatnich lat jest niewątpliwie zaangażowanie części światowego establishmentu na rzecz liberalizacji przepisów antynarkotykowych. Przykład takiej postawy stanowi amerykański finansista George Soros, który od połowy lat 9o. ubiegłego wieku jest jednym z najważniejszych sponsorów licznych inicjatyw w całym świecie, gdy chodzi o promocję legalizacji marihuany i innych narkotyków miękkich.

Spór ideowy i polityczny wokół kwestii legalnego dostępu do narkotyków, prowadzony obecnie w wielu krajach świata, wymaga m.in. pogłębionej analizy filozoficznej fenomenu godności człowieka, wolności czy świadomości. Na gruncie filozoficznym można wypracować adekwatną argumentację, wykazującą nieetyczność używania narkotyków oraz konieczność przepisów prawnych zakazujących uprawy, wytwarzania i dystrybucji tego rodzaju substancji psychoaktywnych w celach rekreacyjnych. 


\section{Bibliografia}

Cekiera Cz., 2005, Narkomania, w: Encyklopedia bioetyki. Personalizm chrześcijański. Głos Kościoła, red. A. Muszala, Polskie Wydawnictwo Encyklopedyczne, Radom, 310-315.

Ciabattoni G., 2004, Farmaci, in: Nuovo Dizionario di Bioetica, red. S. Leone, S. Privitera, Città Nuova Editrice - Edizioni ISB dell'Istituto Siciliano di Bioetica, Roma - Arcireale, 483-487.

Cinquini F., 2016, Dottor Cannabis. La storia di un medico antiproibizionista, Dissensi Edizioni, Viareggio.

Ciociola P., 2016, Dall'erba alle altre droghe è un passo, fermate quel ddl, Avvenire, nr 177, 10.

Firenzuoli F., Epifani F., Loiacono I., 2015, Cannabis. „Erba” medica. Norme, preparazioni galeniche, attualità e prospettive di cura, Edizioni Edra, Milano.

Guerrieri A., 2016, Ddl cannabis all'esame della Camera, Avvenire, nr 174, 7.

Hartung B., Kauferstein S., Ritz-Timme S., Daldrup Th., 2014, Sudden unexpected death under acute influence of cannabis, Forensic Science International, nr 237, 11-13.

Introvigne M., Mantovano A., Serpelloni G., 2015, Libertà dalla droga, Sugarco Edizioni, Milano.

Liverani L., 2016, Cannabis „legale”, contro su Cantone, Avvenire, 196, 9.

Ludovici G. S., 2016, La dignità umana se ne andrà in fumo, Avvenire, nr 174, 3.

Murray Th. H., Gaylin W., Macklin R., 2011, Feeling Good and Doing Better: Ethics and Nontherapeutic Drug Use, Humana Press, New York.

Pach J., 2009, Zarys toksykologii klinicznej, Wydawnictwo Uniwersytetu Jagiellońskiego, Kraków.

Picariello A., 2016, Proposta assurda, a rischio i nostri ragazzi, Avvenire, nr 176, 5.

Piotrowski J., 2008, Podstawy toksykologii, Wydawnictwo Naukowo-Techniczne, Warszawa.

Risé C., 2007, Cannabis. Come perdere la testa e a volte la vita, Edizioni San Paolo, Cinisello Balsamo.

Saviano R., 2008, Gomorra - podróż po imperium kamorry, tłum. A. Pawłowska-Zampino, Wydawnictwo Czytelnik, Warszawa.

Spagnolo V. R., 2016, Cannabis, il testo rimandato a settembre, Avvenire, nr 176, 5 .

Szukalski B., 2005, Narkotyki - kompendium wiedzy o środkach uzależniajacych, Instytut Psychiatrii i Neurologii, Warszawa.
Ślipko T., 2005, Zarys etyki szczegótowej, t. I, Etyka osobowa, Wydawnictwo WAM, Kraków.

White J., 2012, Patients, Drugs E Ethics: Controversies in Pharm, Jones \& Bartlett Publisher, Burlington.

(Web-01) Quinto D., L'establishment mondiale vuole la droga libera, http://www.lanuovabq.it/it/ articoli-lestablishment-mondiale-vuole-la-droga-libera-5386.htm, dostęp: 25.09.2016.

(Web-02) National Institute on Drug Abuse, https://www.drugabuse.gov/about-nida, dostęp: 25.09.2016.

(Web-o3) Mantovano A., Cannabis, riparte il circo degli spinellati, http://www.lanuovabq.it/it/articoli-cannabis-riparte-il-circo-degli-spinellati-8155. htm, dostęp: 25.09.2016.

(Web-o4) Mantovano A., Breve storia delle leggi anti-droga, http://www.lanuovabq.it/it/articoli-breve-storia-delle-leggi-anti-droga-8872.htm, dostęp: 25.09.2016.

(Web-05) Di Lorenzi C., Cannabis, quanto poco ne conosciamo gli effetti, http://www.lanuovabq.it/it/ articoli-cannabis-quanto-poco-ne-conosciamogli-effetti-11712.htm, dostęp: 25.09.2016.

(Web-o6) Santambrogio L., Marijuana libera Il fumo di Saviano è davvero tossico, http://www. lanuovabq.it/it/articoli-marijuana-liberail-fumodi-savianoe-davvero-tossico-11785.htm, dostęp: 25.09.2016.

(Web-o7) Mantovano A., Le solite quattro grandi bugie sulla cannabis libera, http://www.lanuovabq. it/it/articoli-le-solite-quattro-grandi-bugie-sullacannabis-libera-1330o.htm, dostęp: 25.09.2016.

(Web-o8) Lavelli A., Fatti mandare dalla mamma... a fumar canne, http://www.lanuovabq.it/it/articoli-fatti-mandare-dalla-mamma-a-fumarcanne-16464.htm, dostęp: 25.09.2016.

(Web-o9) Mantovano A., Cosi la cannabis libera rovinerà $i$ ragazzi e farà ricche le mafie, http:// www.lanuovabq.it/it/articoli-cosi-la-cannabislibera-rovinerai-ragazzi-e-fara-ricche-le-mafie-16891. htm, dostęp: 25.09.2016.

(Web-10) Mantovano A., Fatela girare. Tutti i luoghi comuni sui benefici della legalizzazione delle droghe leggere, smontati uno per uno, http://www. ilfoglio.it/politica/2016/o8/19/cannabis-legalizzazione-saviano_-_1-v-146135-rubriche_c258.htm, dostęp: 25.09.2016. 


\section{Ethical and legal aspects of the legalization of marijuana and other soft drugs}

\section{Summary}

The main purpose of this article is to present the most important ethical and legal aspects of the legalization of marijuana and other soft drugs. The dispute over the legalization of access to the usage of drugs is an elevation to the point of moral revolution, which is currently engaged on a global scale. Over the past decade there has been strong shift in public opinion in many countries in favor of drug policy reform. Arguments about the prohibition of drugs and over drug policy reform are subjects of considerable controversy. The problem of legal access to drugs is a very complex interdisciplinary issue which requires a reliable diagnosis on the borderline of ethics, medicine, philosophy, law, sociology and political philosophy. The ethical evaluation of the usage of drug and distribution should always precede the adoption of specific measures of a legal nature.

\section{Key words}

drugs, marijuana, cannabis leaves, legalization of drugs, human dignity, drug addiction, soft drugs 